\title{
Gerard Genette and the Categorization of Textual Transcendence
}

\author{
Sayyed Ali Mirenayat \\ PhD candidate in English Literature, Faculty of Modern Languages and Communication, Universiti Putra Malaysia \\ Elaheh Soofastaei \\ PhD candidate in English Literature, Faculty of Modern Languages and Communication, Universiti Putra Malaysia \\ ali.mirenayat@yahoo.com, ela.soofastaei@yahoo.com
}

\section{Doi:10.5901/mjss.2015.v6n5p533}

\section{Abstract}

A text relation with other texts has been a significant subject, which attracted the consideration of researchers, such as Julia Kristeva, Roland Barthes and etc. within Structuralism and Post-Structuralism. Gerard Genette, a French literary theorist, is one of the researchers who define "transtextuality" as a theory which is used when we are not sure about the interpretation of one text that we are reading. His theory describes the different methods in later text which motivates us to read an earlier one. This is the important reason that I have decided to look at his different methods. Genette broadens the study area of Julia Kristeva about "intertextuality" as a theory pointing to relation between various texts. He defines five categories of transtextuality, including intertextuality, paratextuality, metatextuality, architextuality, and hypertextuality, which this paper will explore them as Genette's textual transcendence.

Keywords: Transtextuality, Intertextuality, Paratextuality, Metatextuality, Architextuality, Hypertextuality, Hypotextuality

\section{Introduction}

A text is ... a multidimensional space in which a variety of writings, none of them original, blend and clash. The text is a tissue of quotations ... The writer can only imitate a gesture that is always anterior, never original. His only power is to mix writings, to counter the ones with the others, in such a way as never to rest on any one of them. (Barthes, 1997)

A literary work is created of "a text, defined (very minimally) as a more or less long sequence of verbal statements that are more or less long endowed with significance". But it is "rarely presented in an unadorned state, unreinforced and unaccompanied by a certain number of verbal or other productions" (Gerard, 1997b:1).

In the 1960s, it was Julia Kristeva who used "Intertextuality" for the first time, pointing to any relation between different texts. A theory of the text that expands the identity of the text to include its origins in and its uses of texts of the past is Intertextuality. No text is self-born and every text of the present is an inter-text with something happening between it and a text of the past. After that, Gerard Genette widened the study area of Kristeva, and called relation between a text with other texts or different from its own as "transtextuality" or textual transcendence and he subdivided this type into five categories where intertextuality was only one type.

As for transtextuality, Genette says that "all that sets the text in a relationship, whether obvious or concealed, with other texts" which it "covers all aspects of a particular text" (1992, pp 83-84). He examines the relation between a text with other texts broader and more systemic than Julia Kristeva and Roland Barthes. Genette's studies involve territory of structuralism, post-structuralism and semiotics too, and this permits him to examine intertextual relationships with all its variables. He calls the collection of these relations, "transtextuality". Transtextuality is how to communicate a text with other texts. His transtextuality continued with his book Palimpsestes (1982).

Other categories were called "architextuality", "paratextuality", "metatextuality" and "hypertextuality", each with their own subcategories. Of all these categories, Intertextuality and Hypertextuality study the relationship between two artistic texts, whereas Transtextuality is the study of the relation of a text to the related hypertext. On the other hand, Paratextuality probes into the relation of a text to other connected or separated texts. 


\section{What Is Intertextuality?}

Intertextuality was refined by Genette in 1997 with a term, namely transtextuality, by Graham Allen as "intertextuality from the viewpoint of structural poetics - the theory of reading that investigates, rather than particular works, systems within which texts are constructed, with or without readers' or writers' awareness" (Morris, 2007).

Intertextuality topics had great effect on Tel Quel Thought which Philippe Sollers, Jacques Derrida, Roland Barthes and Julia Kristeva were members of it. In their sight, intertextuality is one of the aspects of shaping the text. Elements that often cannot identify their sign clearly and it doesn't need to identify them. Intertextuality causes dynamism and poly-tonic and no text is without intertextuality. Barthes clearly declares it and says that every text is intertextual. According to Genette, intertextuality involves all relations of a text with other texts.

Intertextuality in Genette's idea is different from Kristeva's idea, because Genette's intertextuality has more limited dimensions. Also, intertextuality is the relationship between two texts according to the co-presence. In other words, if part of a text (text 1) attends in the other text (text 2), the relationship between them is intertextual. Genette uses the term "intertextuality" for a rich mosaic of echoes of, quotations from, allusion to and parallelisms with other texts in a text such as The Waste Land by T.S Eliot.

Intertextuality includes quotation, plagiarism, and allusion. Genette divides intertextuality into three large categories: implicit or explicit; covert or overt; hidden or open.

For the first one, explicit intertextuality expresses overt presence of a text in the other text. In clearer word, in this kind of intertextuality, second text's author doesn't intend to hide his/her text's reference (first text). So we can observe the presence of other text in it. From this perspective, quotation is considered as intertextuality. For the second one, covert intertextuality indicates the hidden presence of a text in another text. In other words, this kind of intertextuality tries to hide its intertextuality reference and this secrecy is not only because of literary necessities, but also it has extra literary reasons. Plagiarism is considered one of the most important implicit intertextuality. Plagiarism is use of another text without permission and mention of reference. And for the last one, sometimes the second text's author is not going to hide his/her intertextual and because of that, he/she uses signs that we can recognize intertextual and even its reference. But this act has never been done explicitly and it is sufficient to implicit allusions because of literary reasons. So implicit intertextuality announces its reference not alike explicit intertextuality and not tries to hide like implicit intertextuality. The most important forms of this intertextual are allusions, allegories and metaphors. Genette says: its less explicit form is allusion; it means that it should be to have high intelligence to understand the relationship between a text and another text that it returns some parts to it necessarily.

\section{Paratextuality}

Para means "beside" and paratextuality is the relation between a text and its 'paratext' - that which surrounds the main body of the text - such as titles, headings, prefaces, acknowledgements, footnotes, illustrations, and etc. In Genette's view, paratextuality comprises,

Those liminal devices and conventions, both within the book (peritext) and outside it (epitext), that mediate the book to the reader: titles and subtitles, pseudonyms, forewords, dedications, epigraphs, prefaces, intertitles, notes, epilogues, and afterwords - all those framing elements that so engaged Sterne; but also the elements in the public and private history of the book, its "epitext," ... "public epitexts" as well as "private epitexts". (1997b)

To Genette, the paratext marks the components at the threshold of the text in order to direct the acceptance of a text by the readers. "The paratext performs various pragmatic functions which guide the readers to understand when the text was published, who published it, for what purpose, and how it should or should not be read." He also "makes a distinction between paratexts, which are autographic; by the author, and allographic; by someone other than the editor, such as an editor or a publisher. The main function of the autographic or allographic preface is to encourage the reader to read the text, and to instruct the reader in how to read the text properly. With his account of paratextuality, Genette takes a different stance than the post-structuralists who dismissed the authorial intention. The structuralist version of intertextuality reasserts the importance of authorial intention" (Simandan, 31).

Genette is "more fascinated by the fringes and borderlands between regimes that these explorations open up". He claims that "paratext is especially rich in these regions of ambiguity. This the terrain of the paratext poses intriguing problems for any speech-act analysis, situated as it is between the first-order illocutionary domain of the public world and that of the second-order speech-act analysis, situated as it is between the first-order illocutionary domain of the public world and that of the second-order speech-acts of fiction"(1997b: xix).

There is no text without cover, just as Genette says that there is a text barely and always there are terms in cover 
of text which involved directly or indirectly. These texts that involve main text like satellite called Paratextual. Paratextuals are like text threshold that it means to enter the world of text, and it should always to pass thresholds. These thresholds are the same Paratextuals. Genette has allocated a book to Paratextuals called "Threshold". This Threshold consists of "peritext" and "epitext" (ibid).

\subsection{Peritextuality}

We can also call it "joined paratextual". It is a paratextual which has adjoined to the main text and it has related directly. This paratextual has surrounded the main text to the nearest form. Joined paratextuals have their special characteristics. These paratextuals present descriptions about the text that we cannot achieve to the text without these descriptions sometimes. Peritextuality comprises of title, chapter title, preface, epigraph and notes that are "beside" the text and are a part of its meaning. The most memorable "preface" is Coleridge's Kubla Khan; and the most memorable titles of twentieth century are novels such as The sound and the Fury by William Faulkner, Brave New World by Aldous Huxley, The Sun also rise and For Whom the Bell Tolls by Ernest Hemingway, Of Mice and Men and The Winter of our Discontent by John Steinbeck, No Country for Old Men by Cormac McCarthy; and the memorable "notes" to a poem is Eliot's The Waste Land.

\subsection{Epitextuality}

Epitextuals are discontinuous with the text and are associated with the main text indirectly. Epitextuals are indirect thresholds that provide possibility of communication and more advertisement or critique of text. Subject evaluates and critique causes relative differentiation of peritextuals and epitextuals. Epitextuality comprises of newspaper or Journal reviews, publicity events, interviews given by the author, the letters of the author, the cover design, the flap and the blurb or the production aesthetics of the book. According to Genette (1997b), epitextuality "is located outside the actual architecture of the book but is linked to it through various representational forms such as press releases, advertising, brochures, interviews, and articles about its author".

\section{Metatextuality}

Genette defines metatextuality as "one of the notions which he defines with the hyperonym "transtextualite", which is 'tout ce qui le met en relation, manifeste ou secrete, avex d'autres textes' (1997c:70). Metatextuality "denotes explicit or implicit references of one text on another text". In Genette's words, "it unites a given text to another, of which it speaks without necessarily citing it (without summoning it), in fact sometimes even without naming it" (1997a, p4). He "explicitly refers to clear and obvious way, leaving no doubt as to the intended meaning. By implicit references, Genette expects an implied reference, not stated, but understood in what is expressed" (Simandan, 32). So when text 1 criticizes and interprets text 2, their relationship will be metatextual relationship, because text 2 that interprets, criticizes and explains is metatextual rather than text 1. Metatextual relationship can act in explaining, denying or approving of text 1. For example, different kinds of Holy Books' interpretations are interpretation, explanation and description. But many of philosophical works such as Averroes's The Incoherence of the Incoherence is written to denial of Ghazali's The Incoherence of the Philosophers, though there are too lots of critiques confirm and advertise this work.

Metatextuality is explicit or implicit critical commentary of one text on another text. Metatextuality is a book of commentary on a literary text. Metatextuality is the relationship between a text and another text of criticism written "after"(chronologically) it. Criticism or commentary is not extraneous to the meaning of a literary text but integral to it because no text is written not to be read and interpreted. Examples of extraordinary metatext - The Road to Xanadu (1927) by John Livingstone, This Great Stage: Image and Structure in King Lear by Robert Hielman (1948) and The Monarch of Wit by J.B. Leishman (1959). Metatextuality plays a significant role in establishing the "reputation" of a writer. Conversely the absence of metatexts for a text diminishes it and restricts its appeal. Good text invites and inexhaustible tradition of interpretations from which it is inseparable.

One of the special cases of metatextuality is metapoetic texts which is "the mixed dynamics between reflection and productivity, which, situated at the limits of criticism and poetry, freely explores a combination of theory and individual aesthetic practice" (Cornis-Pope 44). He adds, "these metaphoric texts may imply both syntactic experimentation and an inter-semiotic connection of the word to pictorial forms, which means that they become highly involved with aesthetic and ideological processes" (ibid). 


\section{Architextuality}

Architextuality is "the most abstract and implicit of the transcendent categories, the relationship of inclusion linking each text to the various kinds of discourse of which it is a representative" (Genette, 1997b: xix). Architextuality is related to "the designation of a text as the part of a genre or genres. The architextual nature of texts also includes thematic and figurative expectations about texts. Genette states that a very important factor of this type is "the reader's expectations, and thus their reception of the work" (Simandan, 33). Architextuality deals with the relation between a text and a text of its kinds. Genette calls architextuality, the relationship between a work and the genre that work belongs to it. Also, architextuality is the tradition or pool of texts out of which a text of the present emerges. Just as an utterance is an actual realization (parole) of the code of a language (langue), similarly any literary text originates out of a tradition of text.

\section{Hypertextuality and Hypotextuality}

According to Genette, hypertextuality involves "any relationship uniting a text B (hypertext) to an earlier text a (hypotext), upon which it is grafted in a manner that is not that of commentary" (Genette, 1997a:5). Thus, hypertextuality represents the relation between a text and a text or genre on which it is based but which it transforms, modifies, elaborates or extends (including parody, spoof, sequel, translation)" (Simandan, 32). His work also "concerns the way in which a text can be transformed by ways of self-expurgation, excision, and reduction" (ibid). He claims that "all texts are hypertextual, but that sometimes the existence of a hypotext is too uncertain to be the basis for hypertextual reading. In such a case, Genette reminds the reader that a hypertext can be read either for its own individual value or in relation to its hypotext" (ibid).

In hypertextuality, the impact of a text on another text will be examined, not its presence. The overall impact and inspiring is generally desired in hypertextuality. Some literary texts turn their architextual roots in a text of the past into a complex visionary and aesthetic narrative design. Like a palimpsest, "hypertext" discloses an underlying retold "hypotext" in a fascinating aesthetics of superimposition/montage. Examples:

Hypertext

Hypotext

The Hours (1998) Michael Cunningham

The Rings of Saturn (1995) W.G. Sebald

Last Orders (1996) Graham swift

Mrs. Dalloway (1925) Virginia Woolf

Urn Burial (1685) Thomas Brown

As I lay Dying (1931) William Faulkner

A hypertext is the continuing and unconcluded meaning of its hypotext. A hypertext is the future of meaning of its hypotext. The meaning of a hypotext is incomplete without the hypertext that it generates. A hypertext and its hypotext are a sign of the past and the present as a unity of meaning. A hypertext is proof that the past is endless. Intertextuality is a sublime "conversation of time" with a distinct hint of immortality. Texts are not immortal.

Other modes of connections between texts are pastiche, parody, sequel, prequel and retelling. Example of a sequel is Scarlett (1991) by Alexandra Ripley [sequel to Margaret Mitchell's Gone with the Wind]; example of a prequel is The Wide Sargasso Sea (1966) by Jane Rhys [prequel to Jane Eyre]; example of retelling is plays (of the past-like Shakespeare). Unlike hypertextuality in which the present is a continuation of the past, retelling adaptation occurs out of the feeling that the present is different from the past.

\section{Conclusion}

This paper made an attempt to have an exploration of various categories in textual transcendence or transtextuality by Gerard Genette. Before Genette, Julia Kristeva used "intertextuality" which develops the identity of the text. She had a significant contribution to intertextual studies. Actually, she was opened a modern horizon by using the term of intertextuality in twentieth century studies. After Kristeva, Genette develops her study of area and defines "transtextuality" or textual transcendence as the relation between a text with other texts or different from its own. He categorizes into five types in which intertextuality is a text that contains words coming from another text or writer; paratextuality is a text in which we are influenced by items which are not in the text themselves, such as titles; metatextuality which is about to citing of another works' texts in a different text; architextuality which is about a text by title; and hypertextuality which includes something like translation and adaptation which is limited to a text, but also to film, painting, and even music.

\section{References}

Cornis-Pope, Marcel. (2014) New Literary Hybrids in the Age of Multimedia Expression: Crossing Borders, Crossing Genres. John 
Benjamins Publishing Company.

Genette, Gerard.(1992) The Architext: An Introduction. Berkeley: University of California Press, 83-84.

---, (1997a). Palimpsests: Literature in the Second Degree. University of Nebraska Press.

---, (1997b). Paratexts: Thresholds of Interpretation. Jane E. Lewin (trans.), Lincoln NE and London: University of Nebraska Press.

Macksey, Richard. (1997c). Foreword to Genette Paratexts. p xiii, note 3.

Morris, Nigel. (2007). The Cinema of Steven Spielberg: Empire of Light. Wallflower Press.

Harari, Josue. (1980). Textual Strategies. University Paperbacks, pp. 43-44.

Simandan, Voicu Mihnea. (2010). The Matrix and the Alice Books. Published by Lulu Books, pp. 14-35. 